\title{
THE STUDY OF EFFECTIVENESS OF SEVEN-STEP (7E) TEACHING METHOD IN THE PROGRESS OF ENGLISH LEARNING IN STUDENTS SHIRAZ CITY
}

\author{
Morvarid Bozorgpouri \\ Department of Elementary Education, Islamic Azad University, Shadegan Branch, Shadegan, Iran
}

\begin{abstract}
This study aimed to investigate the effectiveness of learning English based on the cyclic model (7E). Accordingly, three language institutes in the Shiraz city were selected and among 203 students of these three institutions by calling 132 were registered as volunteers to participate in training classes. After the implementation 20 questions language standard test designed the researcher and with collaboration of teachers of these institutions 30 students who received a low score on this test were selected as examples. The selected sample was divided into two experimental and control groups by random assignment. Finally, 15 students were randomly assigned to the experimental group and 15 students in the control group. For experimental group seven-step teaching method (7E) was used, while traditional method with no resemblance to the seven-step teaching method (7E) was used for the control group. Teaching with seven-step teaching method (7E) during a month and in 3 sessions per week was performed. Finally, for 12 sessions training content through this teaching method was presented to students. After running the post- test data were collected and were analyzed by SPSS software. A significant difference was found between the mean of control group and experimental group in the pre-test and post-test and language scores with the mean of experimental group compared with the control group, about four score increased, which this increase was statistically significant at the level of $0 / 05(\mathrm{p}=0 / 001)$.
\end{abstract}

Keywords: seven-stage (7E) teaching method, Language students, Cooperative teaching, The Shiraz city

\section{INTRODUCTION}

Today, English language has become the dominant language in various fields such as economics, finance, banking, science, technology, culture and international relations around the world. It also accepted that the fluency in the English language is a key success in life (Gomeleksiz, 2010). For these reasons different people and especially students are doing great efforts to learn the language. In Iran universities also all students have to spend English language lessons and academic achievement in the English language can ensure the success of a student to find work and continue education in higher levels. Academic achievement in learning a second language and affecting factors on it in the past decades has attracted the attention of researchers. In this regard, researchers have considered many factors in academic achievement and have done several studies on the basis of them. Also, researchers have introduced different strategies for language learning and other sciences. This paper aims to in the field of language teaching, to employ one of the most dynamic learning models - cyclic learning model, and examine its effectiveness in this area.

The cyclic learning model is an approach that is consistent with the nature of the exploratory and analytical of language teaching. In the cyclic learning model, firstly student through a simple activity or talk about that is excited in order to actively engage in learning; in continue to gain experience teacher will guide them in such a way that by participating in group activities engage in seeking (Cavallo and Labich, 2001). 
The discovery learning approach that has been presented in the context of leading structuralists theories such as Piaget, Bruner, and Vygotsky, emphasizes that students should be involved in creating and building their knowledge (Fitzpatrick, 2001). The cyclic learning models in different curricula with regular stages of E3, E5 and E7 have been used. The E7 model was used in this study. Cyclic model of E7 includes activities that attract students' attention and interest and arouses their curious and eager to assignments. These activities are generally related to daily events that happen to students. Lack of knowledge of students about the affairs through the use of activities of this cyclical model will be changed. There are many studies showing that the E7 model is more effective than other models and has many applications in teaching and learning. For example, researchers such as Akkar (2005), Balaji et al (2006) Wind (2003), Wilder and Shatluth (2005) Kaynar et al. (2009), Brown and Sandra (2007), Ceylon and Gyban (2009) have carried out researches on this field and their findings suggest that the applying of this model and its superiority over the older versions. Cyclic E7 model consists of steps such as understanding, engaging, explore, explain, extend, generalize, and evaluation (Balbal, 2010). One of the differences between E7 and E5 models is that engaging stage is divided into two categories, which are called deduction and engaging. As well as the development and evaluation stages have been extended to three components: expansion, extension and evaluation.

The deduction gives the student the possibility to evaluate every idea or wrong information about different concepts; this stage also concentrates on forcing learners to retrieve and modify existing experiences that are associated with new knowledge. In the engaging stage teacher may evaluate a related scenario or a simple experience for attracting attention of students by asking questions in their minds and use their prior knowledge about the subject matter of the course. The purpose of this step is to thrill students and interesting them in any possible way to matter of course. In the explore stage students are encouraged to struggle with materials and subjects and explore how objects work and speak together and with the teacher or group leader. This stage provides an opportunity for students to observe and record data, propose hypotheses and organize their findings (Shaheen et al., 2015). Teachers can organize questions, propose the method and assess the knowledge. In the explanation stage, students are informed about patterns, laws and theories. Teacher consistently lead students to organized and compatible generalizations and assist students with distinguished academic vocabulary and provides some questions that will assist the students to use this vocabulary for explain the results of their exploration. In the expansion stage students have the opportunity to apply their knowledge for new areas that can be included posing new questions and hypotheses for study (such as language structures, rules and grammar, and providing different subjects). The details associated with mental structure called the transfer of learning. The evaluation stage includes strategies that will help the continuing of final and developmental evaluation of students learning (Abdi, 2014).

Finally, the cyclic learning model is an active method emphasizing on production, control and expansion of knowledge. This model, with a greater emphasis on the importance of deduction of the understanding and perception of students and the development and transfer of concepts, provides their growth and success including thinking (Inskaref, 2003). As mentioned earlier, this study is an attempt to examine whether the cyclic learning model (E7) in teaching English language learners is effective or not?

\section{MATERIALS AND METHODS \\ RESEARCH METHOD, POPULATION AND SAMPLES}

This study is semi-experimental in which two groups of experimental and control with pre-test and posttest has been used. Research population in this study consisted of all students of three language institutes in the Shiraz city that their number was 203. Research sample was selected among these students. For sample selection the following stages were done: At the beginning the teaching method of these three institutions was explained to the headmasters and their consent to pilot this teaching method was taken.

Submit Date: 10.05.2016, Acceptance Date: 25.06.2016, DOI NO: 10.7456/1060JSE/002 
Then, in collaboration with the headmasters of these three institutions three teachers of the institute were randomly selected and 7E learning method was introduced to them over 3 sessions.

Finally, a call to participate in the training class was presented to students. Among all students of these three institutions, 132 students of said they were interested in participating in the sessions and finally, according to their obtained scores in the entrance test (pre-test) and inclusion criteria adopted by the researcher and in consultation with the teachers of these institutions 30 students were selected randomly. The 30 selected people were randomly assigned into two groups of experimental and control. For experimental group seven-step teaching method (7E) was used, while traditional method with no resemblance to the seven-step teaching method (7E) was used for the control group. Finally, after completing the course and teaching, post-test was performed for control and experimental groups.

Control and experimental groups training lasted about a month and three sessions per week that finally, language learners pass 12 sessions of training.

\section{ASSESSMENT TOOL}

In this study, to assess the level of knowledge of students English language a 20 questions standard test was used. This 25 questions test was designed by the three language teachers based on predicted course material. The considered material course was selected based on the level of students. This questionnaire was four- option and its scoring was based on three false option one valid option, commonly known as zero and one scoring. Content validity of the questionnaire by a number of teachers of these three institutions was approved its reliability was assessed by Cronbach's alpha coefficient which was about $0 / 76$. The reliability of the questionnaire was also reviewed by test-retest and obtained correlation of the dual implementation of the questionnaire was about $0 / 83$ that shows a good amount.

\section{ANALYSIS METHOD}

The results of implementation of standard language questionnaire were analyzed through descriptive and inferential statistics. In the descriptive statistics, mean and standard deviation of experimental and control groups were calculated and in inferential statistics Kolmogorov-Smirnov test for normality of data distribution was used in the first stage and in the next step to compare two groups of experimental and control, independent t-test was used. The analysis was done by software SPSS.

\section{RESULTS}

In this study, two groups of experimental and control based on the type used teaching method were used in the testing process. Standard language test implementation for two groups gave data and this data using the software SPSS were analyzed in this section. The descriptive characteristics of sample are shown in table 1 .

Table 1 The mean and standard deviation of the age of study participants

\begin{tabular}{cccccc}
\hline $\begin{array}{c}\text { standard } \\
\text { deviation }\end{array}$ & Mean & Lowest & Highest & Groups & Variable \\
\hline $7 / 43$ & $18 / 23$ & 18 & 22 & Experimental & Age
\end{tabular}

As the above table shows, mean age of experimental group is $(18 / 23)$ and control group is $(18 / 72)$ which their standard deviation also is equal to $7 / 43$ and $7 / 66$, respectively. The education level of sample is also the diploma and bachelor degree (mainly third-year undergraduate).

To compare two studied groups in the pre-test and post-test specific tests for mean comparison should be used, but before implementing them, for determining the use of parametric or non-parametric test, Kolmogorov-Smirnov test was used which in Table 2 is shown.

Table 2 Kolmogorov-Smirnov test for normality of data 


\begin{tabular}{cccc}
\hline p-value & Z- KolmogorovSmirnov & $\begin{array}{c}\text { Mean( standard } \\
\text { deviation) }\end{array}$ & variable \\
\hline $0 / 62$ & $0 / 75$ & $(2 / 94) 11 / 33$ & $\begin{array}{c}\text { Pre-test of experimental } \\
\text { group }\end{array}$ \\
$0 / 80$ & $0 / 64$ & $(2 / 46) 11 / 26$ & Pre-test of control group \\
\hline
\end{tabular}

As Table 2 shows, the distribution of student's scores in pretest is a normal distribution because calculated $z$ value at $0 / 05$ isn't significant. Therefore, parametric tests can be used and in this study for this purpose t-test for two independent groups is used, which its results are shown in Table 3.

Table 3 Comparison the means of experimental and control groups

\begin{tabular}{|c|c|c|c|c|c|}
\hline p-value & $\mathbf{t}$ & $\begin{array}{c}\text { mean (standard } \\
\text { deviation) }\end{array}$ & \multicolumn{2}{|c|}{ Groups } & Variable \\
\hline \multirow[t]{2}{*}{$0 / 94$} & \multirow[t]{2}{*}{$0 / 067$} & (2/94) 11/33 & Experimental & \multirow[t]{2}{*}{ Pre-test } & \multirow[t]{2}{*}{$\begin{array}{l}\text { Language } \\
\text { score }\end{array}$} \\
\hline & & $(2 / 46) 11 / 26$ & Control & & \\
\hline \multirow[t]{2}{*}{$0 / 001$} & $7 / 64$ & (1/52) $16 / 20$ & Experimental & \multirow[t]{2}{*}{ Post-test } & \\
\hline & & $(1 / 76) 11 / 60$ & Control & & \\
\hline
\end{tabular}

As seen in Table 3, the calculated to compare pre-test means of language score of two groups of experimental (11/33) and control (11/26) is $0 / 067$ that this amount is not statistically significant $(0 / 94)$, therefore it could be said that the two groups at the beginning of the study had not significant differences. But after implementation of dependent variable and post-test, the t calculated for comparing two groups of experimental (16/20) and control $(11 / 60)$ was obtained $7 / 64$ which is statistically significant ( $\mathrm{p}=0 / 001)$.

\section{CONCLUSION}

This study aimed to investigate the effectiveness of learning English based on cyclic model (7E) of learning. Accordingly, a sample of over 30 students of three language institutes were selected and were divided into two groups, randomly. In the experimental group students were trained based on seven-stage learning while in the control group teaching was based on traditional teaching approaches that had no resemblance with seven stage approach. After the implementation of posttest data were collected and were analyzed by SPSS software.

The first finding was that the mean of experimental group in post-test compared to pre-test had a significant increase so that the mean score increased about 4 scores, while the mean of control group in the pre-test and post-test had a minor difference $(0 / 40)$. Further results of $t$ test showed that the difference in means of control and experimental groups after the implementation of dependent variable had a significant difference $(\mathrm{p}=0 / 001)$.

In explaining the findings can be expressed as previously proposed learning based on seven-stage model is mainly designed in order to students actively participate in contents and what they are supposed to learn (Sunal and Sonalan, 2008). This teaching method is based on the concepts such as deduction, engaging, exploration, explanation, expansion, generalization, and evaluation that the learner in each of them acts like a prober that with specific purpose, evaluate programs and curricula, and at every stage obtain a 
special knowledge which this knowledge is based primarily on experience and theory (Sasmaz and Tezjan, 2008).

According to Mesit (2006) in this method of teaching, critical thinking as a very important learning factor is used and performed greatly such that at every seven stages the students regularly assess and deduce what they are encountered and these two components are basic for critical thinking.

According to Thomson and Sayba (2003) the positive characteristic of critical thinking is that learners throughout the learning process are aware of what they are learning and matters are transferred to them such a way in which internalization of concepts occurred thoroughly. Also in this method of teaching, teachers in addition to teaching new concepts evaluate the learner's prior knowledge in relation to new teaching materials and elements; such a linkage between students' current knowledge and previous knowledge causes students do not consider new knowledge as strange and sees them in line with previous knowledge and create a systematic classification. In this regard, English language training is one of the areas that students usually start learning it from schools. Since English language in Iran isn't taught based on appropriate principles and rules of language and hence students in cases such as the correct pronunciation of vocabulary, reading, writing and listening are usually very weak and full of mistakes which makes it difficult for them to learn the next basics. Teaching methods based on seven stages, as mentioned work also on this weakness of students. Accordingly, the academic achievement of students in the experimental group can be described considering such expected factors. The results of research are consistent with Abdi (2014), Hawk and Kayani (2015), Mesit (2006), Doghro and Takaya (2008), Wilder and Shalvorth (2005), Baybi (2006), Kazempour (2013).

\section{RECOMMENDATION}

The seven-stage learning with providing new concepts and programs in teaching has opened new chapter in transferring of knowledge to students and learners in different areas. It is recommended that English and other languages teaching institutions use seven steps teaching method to optimize the training process. It can also be said that the seven stages teaching method generally in different sciences teaching can bring many benefits for students and their training.

\section{REFERENCES}

Abdi, Ali (2014). The effectiveness of teaching based on seven-stages cyclic learning model of learning cycle in improving critical thinking skills in male students. Thinking and children, Institute for Humanities and Cultural Studies, Issue II, autumn and winter.

Shaheen, M. N. U. K., \& Kayani, M. M. (2015). Improving Students' Achievement in Biology using 7E Instructional Model: An Experimental Study. Mediterranean Journal of Social Sciences, 6(4), 471.

Mest, Ö. (2006). 'The effect of (7E) learning cycle model on the improvement of fifth grade students' critical thinking skills', A thesis submitted to the graduate school of natural land applied sciences of Middle East Technical University.

Doğru A. P. and C. Tekkaya (2008). 'Promoting Students' Learning in Genetics with the Learning Cycle', Journal of Experimental Education, 76 (3).

Wilder, M. \& Shuttlewoth, P. (2005). Cell Inquiry: A 5E learning cycle lesson. Science Activities, 44 (4), 37-43.

Bybee, R. W., Taylor, A. J., Gardner, A., Van Scotteer, P., Powell, J. C., Westbrook, A., \& Landes, N. (2006). The BSCS 5E Instructional Model: Origins, Effectiveness and Applications. Full report. Colorado Springs.

Kazempour, E. (2013). 'The effects of inquiry-based teaching on critical thinking of students', Journal of Social Issues and Humanities, Vol. 1, Issue 3. 
Thompson, J., \& Soyibo, K. (2002). Effects of lecture, teacher demonstrations, discussion and practical work on 10th graders' attitudes to chemistry and understanding of electrolysis. Research in Science \& Technological Education, 20(1), 25-37.

Şaşmaz Ören, F., \& Tezcan, R. (2009). The Effectiveness of the Learning Cycle Aproach on Learners' Attitude Toward Science in Seventh Grade Science Classes of Elemantary School. Elemantary Educational Online, 8(1), 103-118.

Sunal, D. W., \& Sunal, C. S. (2003). Science in elementary and middle school. In L. A. Montgomery (Ed.), the learning cycle. Saddle River, NJ: Merrill-Prentice Hall.

Sunal, D. W., \& Sunal, C.Bulbul, y. (2010). Effects of (7E) learning cycle model accompanied with computer animations on Understanding of diffusion and osmosis concepts, Middle East Technical University. S. Science in elementary and middle school. In L. A. Montgomery (Ed.), the learning cycle. Upper

Ceylan, E. \& Geban, Ö. (2009). Effects of 5E Learning Cycle Model on understanding of state matter and solubility concepts. Hacettepe: University Journal of Education.

Brown, P. L. \& Sandra, K. A. (2007). Examining the Learning Cycle. Science and Children, 58-59.

Kaynar, D., C. Tekkaya and J. Cakiroglu (2009). 'Effectiveness of 5E Learning Cycle Instruction on Students' Achievement in Cell Concept and Scientific Epistemological Believes', Hacettepe University Journal of Education, 37.

Wilder, M. \& Shuttlewoth, P. (2005). Cell Inquiry: A 5E learning cycle lesson. Science Activities, 44 (4), 37-43.

Boddy, N., Watson, K. \& Aubusson, P. (2003). A trial of 5Es: A referent model for constructivist teaching and learning. Research in Science Education. 33 (1), 27-42.

Balc, S., Çakrolu, J. \& Tekkaya, C. (2006). Engagement, Exploration, Explanation, Extension, and Evaluation (5E) Learning Cycle and Conceptual Change Text as Learning Tools. Biochemistry and Molecular Biology Education, 34(3), 199-203.

Akar, E. (2005). Effectiveness of 5E learning model on students' understanding of acid-base concepts. Thesis: Master of Education. Turkey: Middle East Technical University.

Fitzpatrick, H. (2001). Teaching Strategy: Inquiry Learning. Adolescent Learning and Development Research Paper, 2.

Cavallo, A.M.L. \& Laubach, T.A. (2001). Students' Science Perceptions and En- rollment Decisions in Differing Learn- ing Cycle Classrooms. Journal of Re- search in Science Teaching, 38(9), 1029- 1062.

Gömleksiz, Mehmet Nuri. (2010). An evaluation of students' attitudes toward English language learning in terms of several variables. Procedia - Social and Behavioral Sciences, 9(0), 913-918. doi:

http://dx.doi.org/10.1016/j.sbspro.2010.12.258 